\title{
Glyphosate Effectiveness in the Control of Macrophytes UNDER A GREenHOUSE CONDITION ${ }^{1}$
}

\author{
Eficácia do Glyphosate no Controle de Macrófitas em Condição de Casa de Vegetação
}

CRUZ, C. ${ }^{2,3}$, SILVA, A.F. ${ }^{3,4}$, LUNA, L.V. ${ }^{3}$, YAMAUCHI, A.K.F..$^{3}$, GARLICH, N. ${ }^{3,4}$, and PITELLI, R.A. ${ }^{3}$

\begin{abstract}
The aim of this study was to assess the effectiveness of glyphosate, as Rodeo ${ }^{\circledR}$ formulation, to control Eichhornia crassipes, Pistia stratiotes, Salvinia molesta, Salvinia herzogii and Urochloa subquadripara, under greenhouse conditions. The doses assessed were (480, $960,1440,1920,2400,2880,3360$ and $3840 \mathrm{~g} \mathrm{ha}^{-1}$ of glyphosate) with $0.5 \%$ of the Aterbane ${ }^{\circledR} \mathrm{BR}$ surfactant and a control, with no herbicide application. All experiments were conducted in a completely randomized experimental design with ten replications. Applications were carried out by precision backpack sprayer at a $\mathrm{CO}_{2}$ constant pressure of 25 psi and spray solution consumption of $200 \mathrm{~L} \mathrm{ha}^{-1}$. Product effectiveness was determined by assessing the growth inhibitions and phytotoxicity signals during the periods of $3,7,15,21,30$ and 45 days after application (DAA). At 45 DAA, the highest glyphosate dose (3840 $\mathrm{g} \mathrm{ha}^{-1}$ ) displayed 100\% effectiveness for all four macrophyte species. Under greenhouse conditions, the glyphosate in formulation Rodeo ${ }^{\circledR}$ with $0.5 \%$ of Aterbarne ${ }^{\circledR}$ BR surfactant showed excellent effectiveness, inhibiting the growth of the floating aquatic macrophytes. This procedure can be included on the tillage plans for these species.
\end{abstract}

Keywords: water hyacinth, water lettuce, salvinia and tanner-grass.

RESUMO - O objetivo deste estudo foi avaliar a eficácia do herbicida glyphosate na formulação Rodeo $o^{\circledR}$ para controle da Eichhornia crassipes, Pistia stratiotes, Salvinia molesta, Salvinia herzogii e Urochloa subquadripara, em condição de casa de vegetação. As doses avaliadas foram: 480, 960, 1440, 1920, 2400, 2880, 3360 e $3840 \mathrm{~g} \mathrm{ha}^{-1}$ de glyphosate, com adição de 0,5\% do surfatante Aterbane ${ }^{\circledR}$ BR e um controle sem aplicação do herbicida. Todos os experimentos foram instalados no delineamento experimental inteiramente casualizado com dez repetições. As aplicações foram efetuadas com pulverizador costal de precisão em pressão constante de $\mathrm{CO}_{2}$ de 25 p.s.i. e consumo de calda de $200 \mathrm{~L} \mathrm{ha-1}$. A eficácia do produto foi determinada avaliando-se inibições no crescimento e os sinais de fitotoxicidade durante os periodos de 3, 7, 15, 21, 30 e 45 dias após a aplicação (DAA). Aos 45 DAA, a maior dose do glyphosate (3840 $\mathrm{g} \mathrm{ha}^{-1}$ ) apresentou 100\% de eficácia para as quatro macrófitas. Em condições de casa de vegetação, o glyphosate na formulação Rodeo ${ }^{\mathbb{R}}$ acrescido de $0,5 \%$ de surfatante Aterbarne ${ }^{\mathbb{B}}$ BR apresentou excelente eficácia, com inibição do crescimento de macrófitas aquáticas flutuantes, e pode ser incluido em um plano de manejo dessas plantas.

Palavras-chave: aguapé, alface d’água, salvínia e braquiária-aquática.

\section{INTRODUCTION}

Aquatic macrophytes have a large spatial and temporal distribution, and many are considered cosmopolitan and found in various biogeographical regions. These plants play an important role in the structure and function of aquatic ecosystems (Chambers et al., 2008).

Much of the negative environmental impacts of anthropogenic activities promote the reduction of biodiversity due to changes

1 Recebido para publicação em 5.1.2015 e aprovado em 9.4.2015.

2 Centro Universitário da Fundação Educacional de Barretos, UNIFEB, Barretos, SP, Brasil, <claudineicruz@gmail.com>; ${ }^{3}$ Núcleo de Estudos e Pesquisas Ambientais em Matologia, UNESP, Jaboticabal, SP, Brasil; ${ }^{4}$ Faculdade de Ciências Agrárias e Veterinárias, UNESP, Jaboticabal, SP, Brasil. 
in water bodies, which favor the development of single-species or poorly diversified colonizations, aquatic macrophytes, as well as reducing the availability of dissolved oxygen, besides impairing navigation, water abstraction, generation of hydroelectric energy, leisure activities and other multiple uses of water (Gettys et al., 2008; Martins et al., 2009).

In terms of control measures, the tillage options of these plants can be used: biological controls with action of natural enemies; mechanical ones, with the removal of the plants of the water body; chemical ones, with the use of products having herbicidal action (Pompêo, 2008).

Chemical control is considered easy to perform and excellently cost-effective in the tillage of plants in aquatic environments. As an example of herbicides that can be used in this control, there are: glyphosate, diquat, 2,4-D, triclopyr, imazamox, imazapyr, penoxsulam, fluridone, carfentrazone, endothall, and copper, which are registered for use in water bodies in the United States (Gettys et al., 2008; Peruzzo et al., 2008).

Glyphosate (N-phosphonomethyl glycine) is a non-selective herbicide, of primary action broad spectrum, which promotes inhibition of enzyme 5-enolpyruvylshikimate-3-phosphate (EPSP) synthase, used in the synthesis of amino acids that are essential for the plants. In addition, it has low toxicity for fish, bacteria and mammals, rapid biodegradation and adsorption in the sediment (Peruzzo et al., 2008), which may explain its use in aquatic environments, requiring the assessment of its environmental dynamics.

The effectiveness of glyphosate to control aquatic weeds in controlled and/or field condition has been demonstrated in several studies (Nelson et al., 2001; Fairchild et al., 2002; Martins et al., 2009; Emerine et al., 2010; Sushila Chaudhari et al., 2012; Campos et al., 2013). However, in Brazil, herbicide glyphosate is not used to control floating and rooted macrophytes due to lack of regulation, and studies such as to the effectiveness of this product under conditions controlled and in the environment are necessary. Therefore, the objective of this study was to determine the effectiveness of glyphosate in formulation Rodeo $^{\circledR}$ with surfactant Aterbane ${ }^{\circledR}$ BR in the control of aquatic macrophytes Eichhornia crassipes, Pistia stratiotes, Salvinia molesta, Salvinia herzogii and Urochloa subquadripara, under a greenhouse condition.

\section{MATERIALS AND METHODS}

Glyphosate was used in formulation Rodeo $^{\circledR}$ (CAS n. 1071-83-6), manufactured by Monsanto do Brasil LTDA. This product contains $648 \mathrm{~g} \mathrm{~L}^{-1}$ of isopropylamine salt of $\mathrm{N}^{-}$ (phosphonomethyl) glycine with $480 \mathrm{~g} \mathrm{~L}^{-1}$ of acid equivalent. The surfactant used was Aterbane ${ }^{\circledR} \mathrm{BR}$ with $466 \mathrm{~g} \mathrm{~L}^{-1}$ (ionic surfactant ether alkylphenol polyglycol mixture), manufactured by Dow Agrosciences ${ }^{\circ}$.

Plants E. crassipes, $P$. stratiotes, S. molesta and $S$. herzogii were grown in polyethylene plastic boxes with a capacity of 2.5 liters, filled with substrate composed of coarse sand $(3.0 \mu \mathrm{m})$, organic substrate and Red Oxisol $(1: 1: 1 ; \mathrm{v} / \mathrm{v})$. The water depth was $10.0 \mathrm{~cm}$ above the substrate, and herbicide application was done when the plants occupied $75 \%$ of the total area of the sample containers (plastic boxes). $U$. subquadripara was grown in pots with a capacity of 3.0 liters, filled with a substrate composed of coarse sand $(3.0 \mathrm{mM})$, organic substrate and Red Oxisol (1:1:1; v/v), with five pointers of $U$. subquadripara per pot.

For each aquatic macrophyte, three experiments were performed, being tested dosages (treatments) of 480, 960, 1440, 1920, 2400, 2880, 3360 and 3840 g i.a. ha ${ }^{-1}$ of the glyphosate added of $0.5 \% \mathrm{vv}^{-1}$ of Aterbane ${ }^{\circledR} \mathrm{BR}$, and one without application (control). All experiments were conducted in a completely randomized design (CRD) with ten repetitions.

The applications were done by precision backpack sprayer at $\mathrm{CO}_{2}$ constant pressure of 25 p.s.i. and spray solution consumption of $200 \mathrm{~L} \mathrm{ha}^{-1}$. The applications were done with an initial temperature ranging from 18 to $25{ }^{\circ} \mathrm{C}$, relative humidity between 70 and $85 \%$ and wind speed 0.5 to $2.0 \mathrm{~km} \mathrm{~h}^{-1}$. After the application, the macrophytes were transferred to a greenhouse with a temperature from 25 to $30{ }^{\circ} \mathrm{C}$ and relative humidity at $60 \%$. The effectiveness assessments were done at 3, 7 , 
$15,21,30$ and 45 days after application (DAA), following the rating scale recommended by the Sociedade Brasileira de Ciência das Plantas Daninhas (Brazilian Society of Weed Science), where 0 corresponds to no injury and 100 to the death of the plant (SBCPD, 1995). The scoring used correspond to the average of five evaluators, who scored individually.

\section{RESULTS AND DISCUSSION}

\section{Effectiveness for Eichhornia crassipes}

There was no effectiveness of glyphosate in control of $E$. crassipes at 3 and 7 DAA in all doses assessed (480, 960, 1440, 1920, 2400, 2880,3360 and $3840 \mathrm{~g} \mathrm{ha}^{-1}$ ); at $15 \mathrm{DAA}$, effectiveness was $41 \%$ in 480 to $1440 \mathrm{~g} \mathrm{ha}^{-1}$, from 61 to $91 \%$ in 1920,2400 and $2880 \mathrm{~g} \mathrm{ha}^{-1}$ and $100 \%$ in 3360 and $3840 \mathrm{~g} \mathrm{ha}^{-1}$; at $21 \mathrm{DAA}$, from 50 to $91 \%$ in 480 to $2880 \mathrm{~g} \mathrm{ha}^{-1}$ and $100 \%$ in doses 3360 and $3840 \mathrm{~g} \mathrm{ha}^{-1}$ (Figure 1A).

The main signals of phytotoxicity observed after the application of glyphosate were: yellowing of leaves and bulbs, burns and leaf necrosis followed by bulb necrosis. At 30 and 45 DAA the effectiveness of control was from 61 to $91 \%$ in 480 to $2400 \mathrm{~g} \mathrm{ha}^{-1}$, and in the highest concentrations tested (2880, 3360 and $3840 \mathrm{~g} \mathrm{ha}^{-1}$ ), of $100 \%$, differing only in the time required for the death of the plant.

The effectiveness of glyphosate in controlling E. crassipes in this study was higher than the one obtained by Neves et al. (2002), with 90\% in doses 2400, 2880, 3360 and $3840 \mathrm{~g} \mathrm{ha}^{-1}$ of glyphosate in 20 and 30 DAA, and similar to the one obtained by Emerine et al. (2010), in $2240 \mathrm{~g} \mathrm{ha}^{-1}$ of glyphosate.

In other studies with E. crassipes, herbicide penoxsulam showed effectiveness higher than $95 \%$ in all doses selected $\left(24.5,49.1\right.$ and $\left.98.2 \mathrm{~g} \mathrm{ha}^{-1}\right)$; with herbicide diquat effectiveness was 40\% (130.8 $\left.\mathrm{g} \mathrm{ha}^{-1}\right)$, at 42 DAA (Wersal \& Madsen, 2010). According to Campos et al. (2013), one of the advantages of the use of glyphosate in comparison to other herbicides is its systemic action in plants, leading to gradual death and slow decomposition of the biomass, not promoting sharp reduction in dissolved oxygen levels in water.

\section{Effectiveness for Pistia stratiotes}

At 3 and 7 DAA of control there was no plant control in none of the doses assessed; at 15 DAA there was control from the dose of $960 \mathrm{~g} \mathrm{ha}^{-1}$, with $40 \%$; at $21 \mathrm{DAA}$, the effectiveness of control was of 45 and $60 \%$ in 480 and $960 \mathrm{~g} \mathrm{ha}^{-1}, 80 \%$ in 1,440 and $1920 \mathrm{~g} \mathrm{ha}^{-1}$ and $90 \%$ in the highest doses (2400, 2880, 3360 and $3840 \mathrm{~g} \mathrm{ha}^{-1}$ ) (Figure 1B).

At 30 and 45 DAA, the effectiveness was of $100 \%$ in 2880 to $3840 \mathrm{~g} \mathrm{ha}^{-1}$ and plant regrowth was not seen. In doses of 480 to $1920 \mathrm{~g} \mathrm{ha}^{-1}$ the effectiveness was of 81 to $90 \%$. However, in the three lowest doses $(480,960$ and $1440 \mathrm{~g} \mathrm{ha}^{-1}$ ) there was plant regrowth. The main observed phytotoxicity signal was depigmentation in the herbicide site of contact, such as yellowing of leaves, burning, and total necrosis of leaves at 2880 to $3840 \mathrm{~g} \mathrm{ha}^{-1}$.

Glyphosate $\left(\right.$ Rodeo $\left.^{\circledR}\right)$, tested by Emerine et al. (2010), showed effectiveness similar $(100 \%)$ to the one in this study in the dose of $2240 \mathrm{~g} \mathrm{ha}^{-1}$, using the same herbicide (glyphosate); and herbicides imazapyr and imazamox applied to $P$. stratiotes showed control of 89 and $98 \%$, respectively, with the dose of $560 \mathrm{~g} \mathrm{ha}^{-1}$, in 35 DAA. According to Langeland et al. (2002), herbicide diquat promoted effectiveness higher than $95 \%$ in doses 2.3, 4.6 and 7.0 $\mathrm{L} \mathrm{ha}^{-1}$ (2300, 4600 and $\left.7000 \mathrm{~g} \mathrm{ha}^{-1}\right)$. The difference in effectiveness presented by the authors may be due to the use of $P$. stratiotes at different growth stages and also of the many herbicides tested.

\section{Effectiveness of control for Salvinia molesta and Salvinia herzogii}

Control higher than $40 \%$ was not seen for S. molesta in all doses (480 to $3840 \mathrm{~g} \mathrm{ha}^{-1}$ ) at 3,7 and 15 DAA, except in the dose of $3840 \mathrm{~g} \mathrm{ha}^{-1}$, which showed an effectiveness of 60\% (15 DAA) (Figure 1C).

At 21 DAA, in the lowest doses $(480$ to $\left.1440 \mathrm{~g} \mathrm{ha}^{-1}\right)$, effectiveness was from 40 to $60 \%$, in the intermediate ones (1920 to $2880 \mathrm{~g} \mathrm{ha}^{-1}$ ), from 60 to $70 \%$, and in the highest doses (3360 and $3840 \mathrm{~g} \mathrm{ha}^{-1}$ ) of $80 \%$. At 30 DAA, effectiveness was from 90 to $95 \%$, in doses 2880, 3360 and $3840 \mathrm{~g} \mathrm{ha}^{-1}$. After 

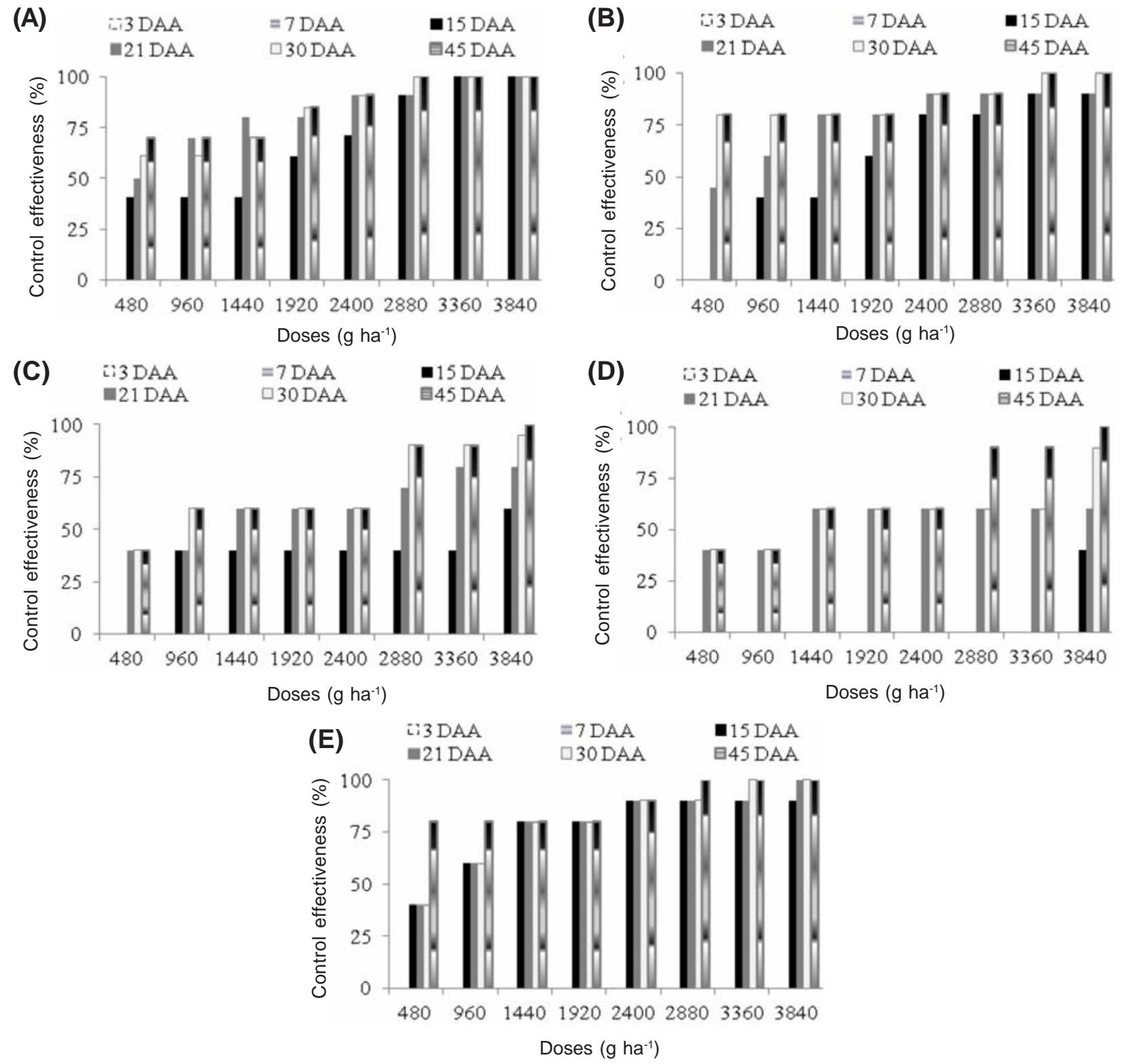

Figure 1 - Percentages of effectiveness of glyphosate with 0.5 of Aterbane ${ }^{\circledR}$ in controlling Eichhornia crassipes (A), Pistia stratiotes (B), Salvinia molesta (C), Salvinia herzogii (D) and Urocloa subquadripara (E).

45 days, the dose of $3840 \mathrm{~g}^{\text {ha }}{ }^{-1}$ showed control of $100 \%$ (Figure 2) for S. molesta; in the other doses $\left(1440,1920,2400,2880\right.$ and $\left.3360 \mathrm{~g} \mathrm{ha}^{-1}\right)$ there was regrowth and in 480 and $960 \mathrm{~g} \mathrm{ha}^{-1}$ the plants showed growth similar to the one in the control treatment at 30 and 45 DAA.

At 3,7 and 15 DAA there was no effectiveness of glyphosate control for $S$. herzogii in all concentrations (480 to $3,840 \mathrm{~g} \mathrm{ha}^{-1}$ ), except for $3840 \mathrm{~g} \mathrm{ha}^{-1}$, which showed $40 \%$ of control (Figure 1D). Control effectiveness from 21 DAA in 1440 and $3840 \mathrm{~g} \mathrm{ha}^{-1}$ was $60 \%$.

At 45 DAA, effectiveness in doses 480, 960, 1440,1920 and $2400 \mathrm{~g} \mathrm{ha}^{-1}$ was from 40 to $60 \%$; in 2880 and $3360 \mathrm{~g} \mathrm{ha}^{-1}, 90 \%$; and in $3840 \mathrm{~g} \mathrm{ha}^{-1}, 100 \%$ (Figure 2). In doses 480 and $960 \mathrm{~g} \mathrm{ha}^{-1}$ there was no control difference in the assessment periods (21, 30 and 45 DAA).

For S. molesta, glyphosate with surfactant Aterbane ${ }^{\circledR}$ showed higher control effectiveness in $3840 \mathrm{~g} \mathrm{ha}^{-1}$, compared to that obtained by 
Nelson et al. (2001), using $0.5 \%$ of adjuvant Cide-Kick, with the highest dose (8970 $\left.\mathrm{g} \mathrm{ha}^{-1}\right)$ than that of this study, with $99.3 \%$ effectiveness.

In the 30 DAA assessment, for S. molesta and $S$. herzogii, the control effectiveness (90 to $95 \%$ in $3840 \mathrm{~g} \mathrm{ha}^{-1}$, respectively) was similar to the one obtained for Salvinia rotundifolia ( 80 to $90 \%$ ) at 15 DAA in doses of 1,060 to $3220 \mathrm{~g} \mathrm{ha}^{-1}$ of glyphosate (Thayer \& Haller, 1985). Fairchild et al. (2002) have assessed glyphosate added of $0.25 \%$ of surfactant LI-700 ${ }^{\circledR}$ and Cygnet $^{\circledR}$ and noticed a control from 90 to $100 \%$ with 1344 ha $^{-1}$ for the same test plant, with control similar to that of this study at 45 DAA.

Several herbicides were also used to control Salvinea molesta, such as imazapyr (1680 $\left.\mathrm{g} \mathrm{ha}^{-1}\right)$, glyphosate (8979 $\mathrm{g} \mathrm{ha}^{-1}$ ), endothall (5040 $\left.\mathrm{g} \mathrm{ha}^{-1}\right)$ and diquat (1120 $\left.\mathrm{g} \mathrm{ha}^{-1}\right)$, with the best effectiveness for glyphosate and diquat (99.3 and $100 \%$, respectively) at 42 DAA (Nelson et al., 2001). Carfentrazone showed effectiveness higher than $91 \%$ in doses 112,168 and $224 \mathrm{~g} \mathrm{ha}^{-1}$ (21 DAA) (Glomski \& Getsinger, 2006) and imazamox showed effectiveness of $89 \%$ with $560 \mathrm{~g} \mathrm{ha}^{-1}$ for S. molesta (Emerine et al., 2010).

The various reported control effectiveness values can be derived from various mechanisms of action of the herbicides and the inherent sensitivity to plants, because, according to Hangelbroek et al. (2002), the genetic diversity and the spatial distribution of the plants are influenced by genetic recombination, which leads to the emergence of new genotypes. Also, this may occur due to the applied herbicide not reaching the leaf epidermis or the amount of products not being sufficient, because of the trichomes present on leaves of Salvinia sp., which act as a barrier to absorption of the herbicide, which may also have contributed to the lower effectiveness and increased chances of recolonization (Pereira, 2003; Wersal \& Madsen, 2010).

\section{Control effectiveness for Urochloa subquadripara}

For $U$. subquadripara there was no control at 3 and $7 \mathrm{DAA}$; at 15 and $21 \mathrm{DAA}$, the control effectiveness ranged from 40 to $90 \%$ in 480 to $3,840 \mathrm{~g} \mathrm{ha}^{-1}$, except for $100 \%$ of control in $3840 \mathrm{~g} \mathrm{ha}^{-1}$ (21 DAA) and in 3360 and $3840 \mathrm{~g} \mathrm{ha}^{-1}$ (30 DAA). In 480, 960 and $1440 \mathrm{~g} \mathrm{ha}^{-1}$, regrowth was noticed from 30 DAA (Figure 1E). At 45 DAA, the control effectiveness in 480, 960, 1440 and $1920 \mathrm{~g}^{\mathrm{ha}^{-1}}$ was $80 \%$; for $2400 \mathrm{~g} \mathrm{ha}^{-1}$, it was $90 \%$; and for 3360 and $3840 \mathrm{~g} \mathrm{ha}^{-1}$ the effectiveness was $100 \%$.

The effectiveness obtained was similar to that by Carbonari et al. (2003), using plants Urochloa subquadripara and U. mutica exposed to glyphosate with surfactants Aterbane $^{\circledR}$ (96 to $98 \%$ and 93 to $97 \%$ of control,

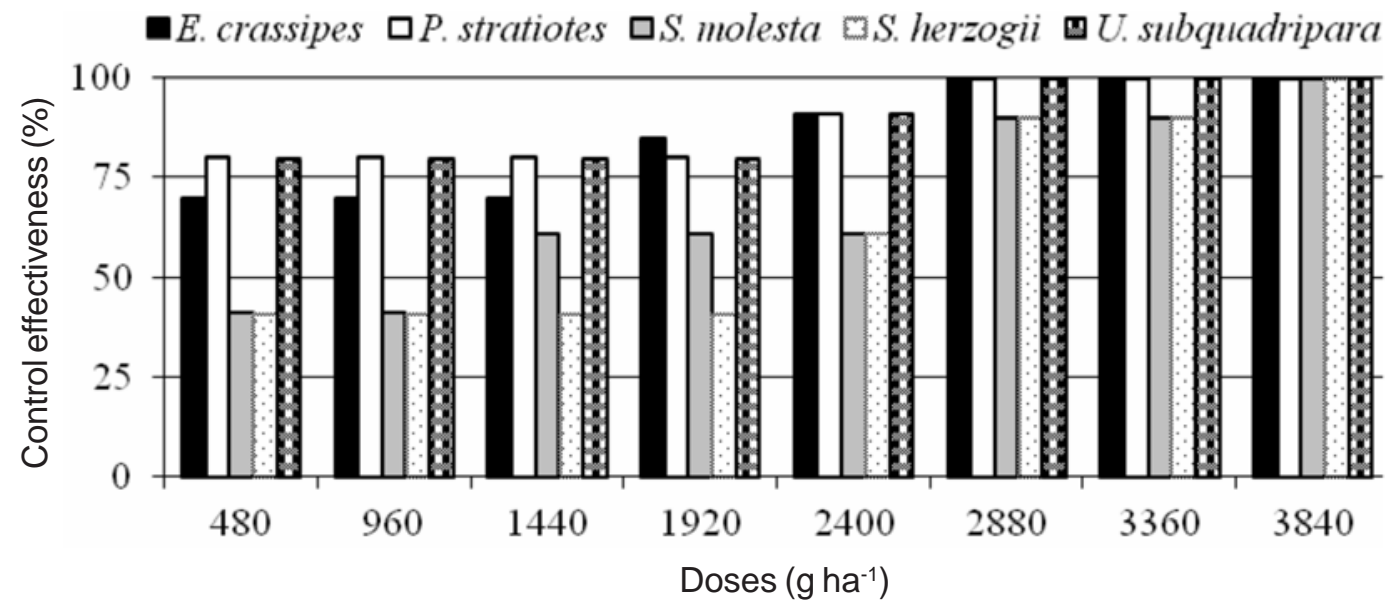

Figure 2 - Control effectiveness of herbicide glyphosate with the addition of $0.5 \%$ of surfactant Aterbane ${ }^{\circledR}$ BR at 45 days after the application. 
respectively) and Silwet ${ }^{\circledR}$ (97 to $99 \%$ and 93 to 97\%, respectively), in 2400 and $3360 \mathrm{~g} \mathrm{ha}^{-1}$.

The glyphosate control effectiveness values in this study for $U$. subquadripara corroborate the ones obtained for Urochloa mutica, being 95 and $92 \%$ in 2,240 and $3,360 \mathrm{~g} \mathrm{ha}^{-1}$ respectively, with $0.25 \%\left(\mathrm{v} \mathrm{v}^{-1}\right)$ of the non-ionic surfactant (Sushila Chaudhari et al., 2012), and for Alternanthera phyloxeroides, Ludwigia grandiflora and Myriophyllum aquaticum (Emerine et al., 2010).

In doses 480 and $960 \mathrm{~g} \mathrm{ha}^{-1}$ the control effectiveness order was: $P$. stratiotes $=$ $U$. subquadripara $>$ E. crassipes $>S$. molesta $=$ S. herzogii; in $1440 \mathrm{~g}^{\text {ha }}{ }^{-1}$ was: $P$. stratiotes $=$ $U$. subquadripara $>$ E. crassipes $>S$. molesta $>$ S. herzogii; in $1920 \mathrm{~g} \mathrm{ha}^{-1}$, E. crassipes > $P$. stratiotes $=U$. subquadripara $>S$. molesta $>$ S. herzogii; in 2400, 2880 and $3360 \mathrm{~g} \mathrm{ha}^{-1}$ : $P$. stratiotes $=U$. subquadripara $=E$. crassipes $>$ S. molesta $=$ S. herzogii, and in $3840 \mathrm{~g} \mathrm{ha}^{-1}$ the effectiveness was $100 \%$ for the five species of macrophytes tested (Figure 2).

In doses 2880 and $3360 \mathrm{~g} \mathrm{ha}^{-1}$, the effectiveness for $U$. subquadripara, $E$. crassipes and $P$. stratiotes was $100 \%$, but for Salviniaceae the same effect (effectiveness) was not observed. In the lower doses the control effectiveness for $S$. molesta and $S$. herzogii was lower, specially for $S$. herzogii.

According to Pereira (2003), the low sensitivity of $S$. molesta and $S$. herzogii in relation to the other species can be explained by their being pteridophytes or pteridophyta, a group that does not have conducting vessels as efficient as the angiosperms. It is important to point out the difficulty of the contact of the herbicide spray solution with the plant leaf epidermis due to the intense hairiness of the leaf surface.

Glyphosate in formulation Rodeo ${ }^{\circledR}$, added of $0.5 \%$ of surfactant Aterbarne ${ }^{\circledR} B R$, promoted control equal ou higher than $90 \%$ in the highest concentrations (3360 and $3840 \mathrm{~g}$ ha $\left.{ }^{1}\right)$ for all plants assessed, showing potential for use in the chemical control of these plants in Brazil. Based on the results, it is possible to conclude that in greenhouse conditions, glyphosate has highly control effectiveness of floating aquatic macrophytes (E. crassipes,
P. stratiotes, S. molesta, S. herzogii and $U$. subquadripara) and it may be included in a chemical tillage plan for these plants.

\section{ACKNOWLEDGMENT}

This work was supported in the form of postdoctoral fellowship by the first author Foundation of the São Paulo State Research. Proc. 2006/50700-5.

\section{LITERATURE CITED}

CAMPOS, C. F. et al. Translocação dos herbicidas glyphosate e imazamox em plantas de aguapé. Arq. Inst. Biol., v. 80, n. 2, p. 177-182, 2013.

CARBONARI, C. A. et al. Controle de Brachiaria subquadripara e Brachiaria mutica através de diferentes herbicidas aplicados em pós-emergência. Planta Daninha, v. 21, n. 1, p. 79-84, 2003.

CHAMBERS, P. A. et al. Global diversity of aquatic macrophytes in freshwater. Hydrobiologia, v. 595, n. 1, p. 9-26, 2008.

SUSHILA CHAUDHARI, B. A. et al. Integrating chemical and culture practiced to control para grass (Urochloa mutica). J. Aquat. Plant Manage., v. 50, n. 1, p. 39-45, 2012.

EMERINE, S. E. et al. Greenhouse response of six aquatic invasive weeds to imazamox. J. Aquat. Plant Manage., v. 48, p. 105-111, 2010.

FAIRCHILD, J. F. et al. Efficacy of glyphosate and five surfactants for controlling giant Salvinia. J. Aquat. Plant Manage., v. 40, n. 1, p. 53-58, 2002.

GETTYS, L. A; 'HALLER, W. I.; BELLAUD, M. (Eds.). Biology and control of aquatic plant: A best management practices handbook. Marietta, GA: Aquatic Ecosystem Restoration Foundation, 2008. 210 p.

GLOMSKI, L. M.; GETSINGER, K. D. Carfentrazone-ethyl for control of giant Salvinia. J. Aquat. Plant Manage., v. 44, p. 136-138, 2006.

HANGELBROEK, H. H. et al. Clonal diversity and structure within a population of the pondweed Potamogeton pectinatus foraged by Bewick's swans. Molec. Ecol., v. 11, n. 10, p. 2137-2150, 2002.

LANGELAND, K. A. et al. Evaluation of a new formulation of Reward landscape and aquatic herbicide for control of duckweed, waterhyacinth, waterlettuce and hydrilla. J. Aquat. Plant Manage., v. 40, n. 1, p. 51-53, 2002. 
MARTINS, D. et al. Ação de adjuvantes na absorção de glyphosate em plantas de aguapé (Eichhornia crassipes). Planta Daninha, v. 27, n. 1, p. 155-163, 2009.

NELSON, L. S. et al. Herbicide evaluation against giant salvinia. J. Aquat. Plant Manage., v. 39, n. 1, p. 48-43, 2001.

NEVES, T. et al. Controle químico do aguapé (Eichhornia crassipes). Planta Daninha, v. 20, n. 1, p. 89-97, 2002.

PEREIRA, A. B. Introdução ao estudo das pteridófitas. Canoas: ULBRA, 2003. 192 p.

PERUZZO, P. J. et al. Levels of glyphosate in waters, sediments and soil associated with direct sowing soybean cultivation in north pampasic region of Argentina.

Environ. Poll., v. 156, n. 1, p. 61-66, 2008.
POMPÊO, M. Monitoramento e manejo de macrófitas aquáticas. Oecol. Bras., v. 12, n. 3, p. 406-424, 2008.

SOCIEDADE BRASILEIRA DA CIÊNCIA DAS PLANTAS DANINHAS - SBCPD. Procedimentos para instalação, avaliação e análise de experimentos com herbicidas: Londrina: 1995. 42 p.

THAYER, D. D.; HALLER, W. T. Effect of herbicides on floating aquatic plants. J. Aquat. Plant Manage., v. 23, n. 1, p. 94-95, 1985.

WERSAL, R. M.; MADSEN, J. D. Combination of penoxulam and diquat as foliar applications for control of waterhyacinth and common salvinia: Evidence of herbicide antagonism. J. Aquat. Plant Manage., v. 48, n. 1, p. 21-25, 2010. 